Farhad Rahmanov,

Dr.Sc., Azerbaijan State University of Economics (UNEC), Republic of Azerbaijan

ORCID ID, 0000-0003-2911-8179

email: farhad_rahmanov@unec.edu.az

Muslum Mursalov,

Ph.D., Azerbaijan State University of Economics, Azerbaijan (UNEC), Republic of Azerbaijan

iD ORCID ID, 0000-0003-4174-8093

email: Mus/um_Mursalov@unec.edu.az

Anna Rosokhata,

Ph.D., Sumy State University, Ukraine

iD ORCID ID, 0000-0001-6944-1515

email: a.rosokhata@gmail.com

Correspondence author: farhad_rahmanov@unec.edu.az

\title{
CONSUMER BEHAVIOR IN DIGITAL ERA: IMPACT OF COVID 19
}

Abstract. The main goal of this paper is to research differences that start to change consumer behavior in the digital era since the advent of COVID 19. The events associated with the pandemic that led to increased social distance and complete lockdown undoubtedly affect not only the economic situation territories and countries in general, but also on the behavior of each individual. The situation that has arisen has forced more and more consumers to meet their needs with the help of digital tools, and this process has some special characteristics. The article shows the results of analytical and comparative analysis of the changes in consumer behavior in the digital space since the onset of the pandemic. It was researched trends change consumer demand in the study categories via Google Trends. The practical study was conducted on the basis of the analysis of changes in consumer behavior and their preferences in the direction of recreation and tourism, where the data of a sociological survey of Azerbaijani citizens to study the potential impact of COVID-19 on the tourism industry was used. The survey was conducted on April 13-21, 2020 by a team of researchers from the University of Northampton (UK), the National Institute of Geophysics, Geodesy and Geography - Bulgarian Academy of Sciences, University of National and World Economy (Bulgaria). According to the results of the study, conclusions were drawn that give new challenges to the development of marketing in the digital environment, namely: digital tools have had rapid unpredictable development since the COVID-19 pandemic, and remain as high level in demand after easing restrictive measures; entrepreneurship was not ready for such quick transformation; after the first interactions in digital space, the consumer has a stable experience of interaction with specific brands, but they disappoint the expectations of consumers in a personalized contact. Based on the conclusions, an algorithm for building relationships with consumers and increasing their level of loyalty in the digital environment is proposed. The results of this study could be used in the implementation of marketing goals of representatives of different levels of business structures, governments.

Keywords: consumer behavior, COVID-19 impact, digital environment, tourism in Azerbaijan, consumer individual changes.

Introduction. The events caused by COVID-19 are one of the most significant and unpredictable events of recent years. Really everyone could say the world has not seen such a large-scale crisis before. Every country, economy, and area of human activity could not ignore the pandemic that has been unfolding since the beginning of 2020. And no doubt it has had a powerful impact on people's behavior as consumers.

In the conditions of the economic crisis, attention to the marketing in practically every business is undoubtedly increasing. Everyone knows that when a business is going through hard times, advertising and marketing budgets are the first to suffer. Although there is an opposite opinion, which says: it is during

Cite as: Rahmanov. F., Mursalov. M., \& Rosokhata, A. (2021). Consumer Behavior in Digital Era: Impact of COVID19. Marketing and Management of Innovations, 2, 243-251. http://doi.org/10.21272/mmi.2021.2-20 
a period of difficulties that marketing tools largely help to maintain the level of sales and, accordingly, stay afloat. The crisis is forcing a number of companies that are ineffective in terms of economics, marketing, and customer service to leave the market. Only those organizations continue to function that really work efficiently and maximally satisfy the requirements of customers. Since the beginning of the crisis, the marketing budgets of most companies have decreased significantly. Most of all, the cost of image advertising and advertising aimed at a wide audience has decreased (television, radio, outdoor advertising and glossy magazines have lost a significant number of advertisers).

At the same time, spending on advertising campaigns targeted at the end consumer has not decreased at all, and in some cases has increased. The cost of BTL-promotions, promotions and presentations, SMS marketing, contextual and banner advertising on the Internet continued to grow. The low cost of such advertising, direct contact with the target audience and the quick response of the consumer provide these methods with increased interest from marketers and company owners - today more and more companies are turning to these tools.

The purpose of the article is to form recommendations for digital marketing as a result of the study of changes in consumer behavior in general caused by the influence of COVID-19 in the digital environment and in particular in the tourism industry of Azerbaijan. The tasks of the paper include a study of the main trends of consumer behavior; study of the stages of transition and orientation to the digital environment; analysis of statistics on these issues in the world; a study of the state of the tourism industry in Azerbaijan in 2020, which has significant changes due to quarantine measures caused by the COVID-19 pandemic; a identification of the main trends of 2020-2021 in digital marketing; formation of recommendations for the development of future marketing strategies in the digital environment.

Literature Review. The use of marketing methods, along with the implementation of measures of a social, economic and political nature, could accelerate the recovery from the crisis, enable the development of individual enterprises and industries, change the perception of consumers, and serve as a kind of prevention of the emergence of crisis phenomena in the future.

The consumer's reaction to product promotion tools has also changed. Most buyers want to be guided in their choice not only by the retail price of the product, but also by its real value. Each of us wants the information in the advertising materials of the companies to be more reliable and honest, including information about the production, composition, formation of the price of the product, which would allow us to more realistically assess its real value. Companies have to meet new market demands.

Recently, more and more people talk about socially responsible marketing, during the crisis, attention to it has grown even more. The scientific works of scientists Vasilyeva et al. (2019), Kwilinski et al. (2020), Rosokhata et al. (2020) are devoted to the study of changes in consumer behavior in the digital environment. At the same time the impact of events caused by COVID-19 was researched by Rahmanov et al. (2020), Kuzmenko et al. (2020), Farseev et al. (2020), Chen et al. (2020), Ji et al. (2020) and others. In general, a lot of scientists explore actual questions about influence healthcare on economy and consumer behavior. It was Us et al. (2020), Vasylieva et al. (2020), Bilan et al. (2021), Rudenko et al. (2020), Yelnikova and Kwilinski (2020) and others. A lot of them showed actual people problem in didgital era during COVID-19, some of them are Carnevale and Hatak (2020), Dutta et al. (2020), Bai et al. (2020), Saher et al. (2020), Donthu and Gustafsson (2020).

Due to the crisis and reduced demand, many manufacturers and especially retailers - the last link in the chain from producer to consumer - are reducing the markup on the product, i.e., its final (retail) value becomes lower. The scientific works of scientists Gritsayenko (2020), Sheth (2020), Armano (2020), Theodoridis and Kavoura (2020) showed problems of changing consumer behavior in digital environment caused COVID-19. Despite the importance of these studies, the scientific importance of changing consumer behavior during quarantine remains relevant. 
The concept of socially responsible marketing includes a whole range of procedures: compliance with environmental standards, and participation in charitable projects, and the solution of social problems of the territories in which the company operates. More and more organizations are using their promotions to raise funds for charitable purposes or to raise awareness of environmental issues, not just to sell additional merchandise. The number of green products is growing, new jobs are being created - all these are the principles of socially responsible marketing in action. Due to the crisis and reduced demand, many manufacturers and especially retailers - the last link in the chain from producer to consumer - are reducing the markup on the product, i.e., its final (retail) value becomes lower. Also, the additional instrument is viral marketing. Its promotion through groups in social networks are gaining more and more popularity during the crisis. These tools help companies reach their customers through other consumers. These methods have their drawbacks, but their main advantage is low cost with a sufficiently high degree of individualization. A recommendation from another consumer allows you to ensure a high level of brand trust, which cannot be achieved with colorful and expensive advertising. One of the promotion methods, which began to be used much more actively during the crisis, is cross-marketing. This tool has been in the arsenal of marketers before, but it has not been used often. Today, when companies have to save on everything, cross-marketing has bided its time: using this method allows you to achieve a synergistic effect in promoting goods / services and reduce the corresponding costs. In the context of the rapid development of the market, not all companies paid attention to service and building long-term relationships with customers. Now interest in them has increased significantly, because most enterprises are experiencing a deficit in the marketing budget, and retaining existing customers is always easier and cheaper than attracting new ones. The widespread implementation of CRM systems (customer relationship management system) has begun, but, unfortunately, low service culture and lack of trained personnel often lead to the fact that even an excellent CRM system is not used with full dedication. In general, it should be noted the increase in attention and research the rapid development of e-commerce, social networks, and Internet projects in various industries. The relatively low «entry threshold» gives rise to a huge mass of projects, but only a few would become effective and profitable.

Methodology and research methods. Analytical and empirical research are the methodological basis of the article. The analytical study was conducted by examining the results of Google Trends on key metrics analyzed in the study. The empirical results of the work were formed based on the marketing research of the citizens of Azerbaijan to study the potential impact of COVID-19 on the tourism industry.

The survey was conducted on April 13-21, 2020 by a team of researchers from the University of Northampton (UK), National Institute of Geophysics, Geodesy and Geography at the Bulgarian Academy of Sciences, University of National and World Economy (Bulgaria).

The sample included 417 citizens, where $69 \%$ were women, and $31 \%$ were men. About $50 \%$ of respondents are young people under 24 years old. The hypothesis of the study was from the moment of quarantine measures related to COVID-19 and the restriction of tourist connections, consumer behavior would be significantly changed, which would have a significant impact on the development of the digital environment.

Results. The last years of development of the world community are characterized by an active increase in consumption of goods and services for all mankind. And with the advent of COVID-19 and the global pandemic, more and more consumers are converting to the digital environment. They face financial difficulties, use increasingly digital technology, and become much more selective in purchasing decisions. From them, the content of trust in the company and brands is changing. Previously, trust meant that the brand kept all its promises. Now it means the priority of customer needs: a sense of security, the preservation of personal data that must be protected. Companies need to focus more on digitally supporting their customers, and have a clear understanding of how they would gain their trust in their 
brand or company in the future. In addition, firms need to develop new tactics to protect price positioning, as price becomes a major factor in making a purchase decision.

Since the beginning of quarantine, some common features in the behavior of consumers in both Ukraine and the world community have been noticed (Heubl, 2020). With the onset of quarantine, no one tried to book a hotel for the next vacation. In general, the change in the nature of consumer demands with the onset of quarantine is presented in Figure 1. That is why the greatest negative impact of quarantine measures had on the tourism industry.

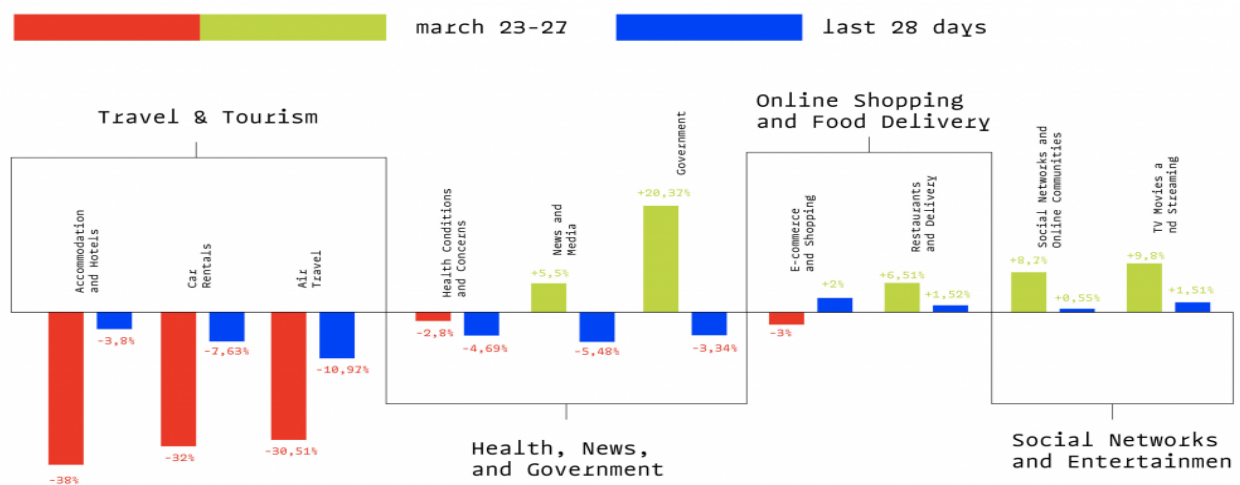

Figure 1. Statistics of changes in consumer demand in the period from March 23-27, 2020 Sources: developed by the authors on the basis of (Gritsayenko, 2020).

During the introduction of strict quarantine measures, it was important for everyone to understand the situation in the world with coronavirus, what decisions the government makes, how it would affect life in the coming weeks, months, whether to buy a monthly supply of food and not leave home (Perez, 2020).

The survey that was conducted on April 13-21, 2020 by a team of researchers from the University of Northampton (UK), the National Institute of Geophysics, Geodesy and Geography - Bulgarian Academy of Sciences, University of National and World Economy (Bulgaria) shows some changes in consumer behavior in tourism area. (Figure 2)
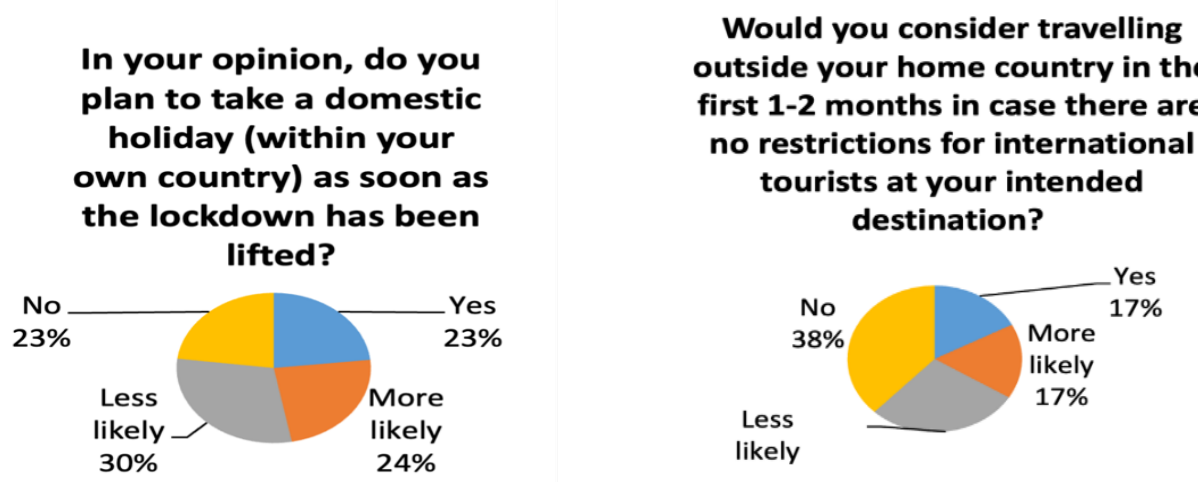

Figure 2. Distribution of changes in consumer preferences under the influence of events caused COVID-19

Sources: developed by the authors. 
This analysis shows among the respondents, the preferences and direction of decision-making change significantly under the influence of COVID-19. The respondents' preferences analysis shows that they have become more sensitive to the demands of the environment and agree to change their intentions in order to maintain good health, especially in the field of recreation and tourism.

Figure 3 shows that with the quarantine of consumers tend to give up live communication and travel to stay healthy. Thus, the analysis of this study emphasizes not only the change in consumer behavior with the advent of COVID-19 but also a clear reorientation of preferences and orientations of consumers from the possibilities of tourism and live communication towards shifting the focus to the digital environment.

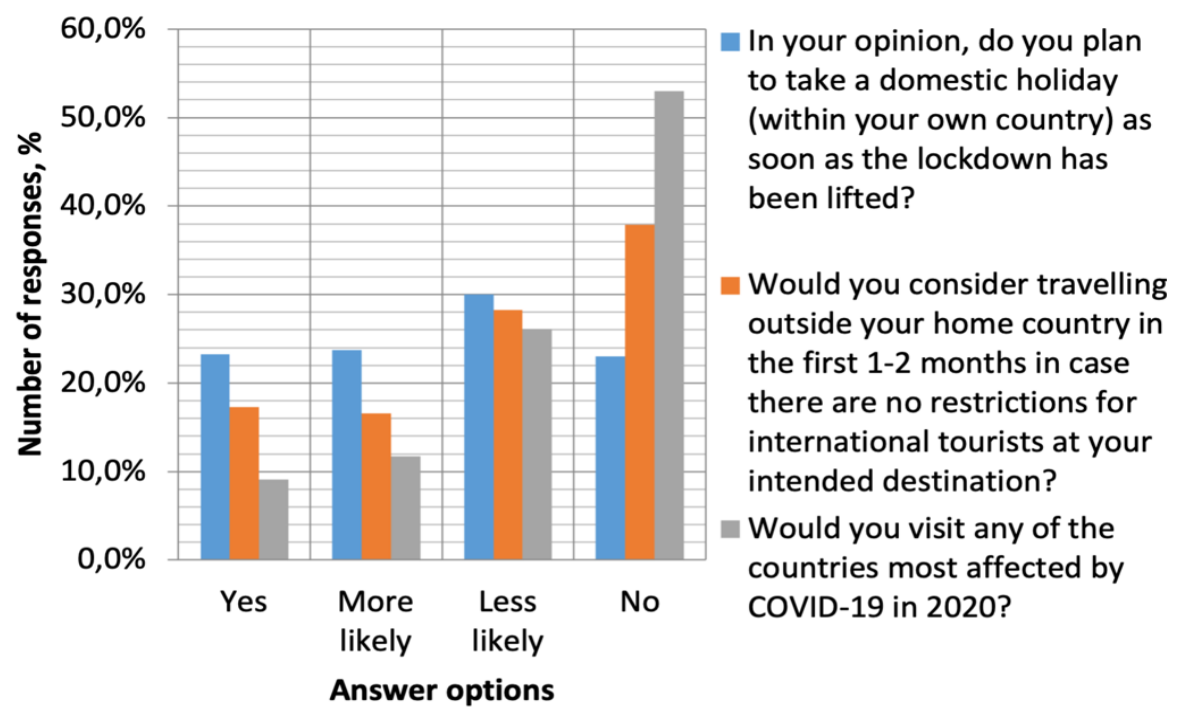

Figure 3. Distribution of changes in consumer preferences under the influence of events caused

Sources: developed by the authors.

COVID-19

During the pandemic, certain specific features of consumer behavior were observed. Thus, contactless payments and online shopping have become commonplace for the majority of consumers. Shopping also decreased. Previously, offline purchases were preferred by about $35-40 \%$ of consumers, now $25 \%$. Many consumers have started buying products in online stores, and they also use products from local manufacturers, rather than well-known global brands.

The population became less likely to go to beauty stores, specialty stores. The percentage of purchases of alcoholic beverages, chips, confectionery fell (Biswal et al., 2020).

The need to work from home online has led to a growing demand for conferencing programs: Zoom, Hangouts Meet from Google. In addition, the popularity of services that allow you to work with large amounts of data (for example, Amazon Web Services). In general, in study we identified 6 stages of changes in consumer behavior during quarantine (Table 1).

As basic needs are met (according to Maslow), the audience adapts the conditions to normal life. There is a demand for online sports, online training, online beauty salon, food from a favorite restaurant, and someone is already starting a preliminary search for tickets and booking hotels for the autumn-winter period, especially with free cancellation. 
Table 1. Stages of changes in consumer behavior

\begin{tabular}{|c|c|}
\hline Stage 1: & $\begin{array}{l}\text { Consumers have started buying products that would help maintain immunity } \\
\text { during quarantine: vitamins, various supplements, etc. }\end{array}$ \\
\hline Stage 2: & $\begin{array}{c}\text { Consumers pay attention to products that reduce the risk of infection, such as } \\
\text { disinfectants, face masks }\end{array}$ \\
\hline Stage 3: & $\begin{array}{l}\text { Begin to actively prepare for quarantine: purchase of essentials: food, cold } \\
\text { remedies, personal care products. The stage is characterized by an increase in } \\
\text { consumer baskets }\end{array}$ \\
\hline Stage 4: & Consumers are sitting at home, the role of online shopping has increased \\
\hline Stage 5: & $\begin{array}{c}\text { Due to rising prices and shortages of different groups of goods, consumers have } \\
\text { become more sensitive to prices }\end{array}$ \\
\hline Stage 6 & $\begin{array}{l}\text { Everyone has returned to their usual routine activities, but the habits that were } \\
\text { developed during the quarantine remain (including the choice of online shopping in } \\
\text { favor of ordinary and active social life in the digital environment) }\end{array}$ \\
\hline
\end{tabular}

Sources: developed by the authors.

The nature of consumption has influenced the formation of new habits for several months, so even with the offline release for many companies, interaction with online customers would remain a priority.

In general, a study of statistics on the global development of the digital environment (Global Digital Growth. The year-on-year change in didgital adoption. January. 2021. Internet users numbers no longer include data sourced from social media platforms) shows an increase in Internet users and a corresponding increase in consumer demand in the digital environment (Fig.4).

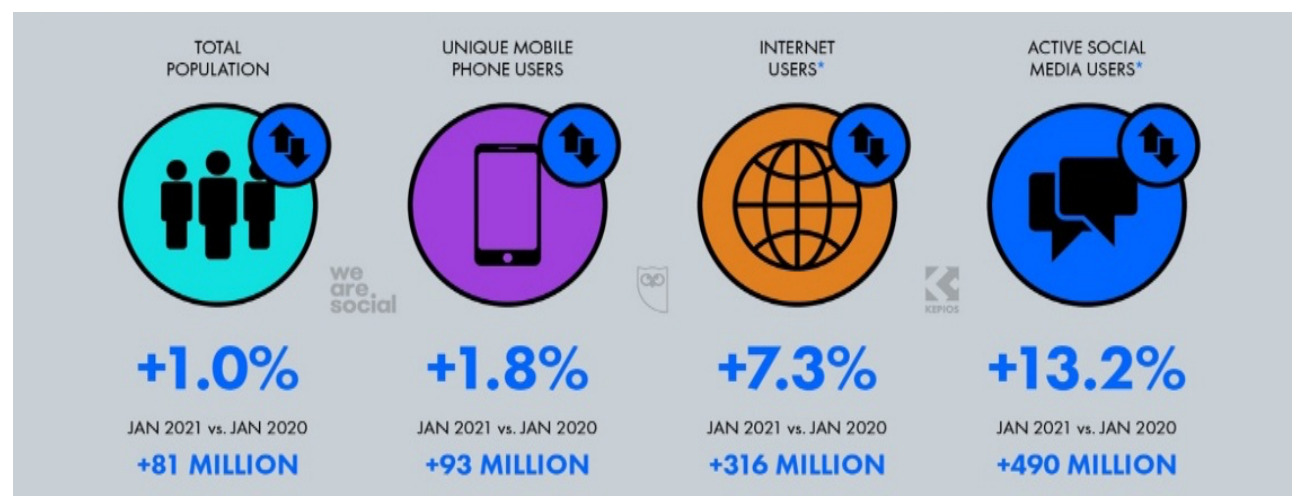

Figure 4. Statistics of Internet users: comparison of 2020-2021

Sources: developed by the authors on the basis of (Kemp, 2021).

In a pandemic, quarantine and the need to maintain social distance have forced consumers to change their main way of shopping. In a couple of months of quarantine, the number of online purchases has increased en masse. This trend continues, especially in the field of basic necessities. Many consumers and companies have plunged sharply into the digital environment. Marketers have a difficult goal to rethink the company's strategy, as well as how to work with consumers. Customers would need a lot of quality content from the resources they trust. You also need to keep in mind that a sharp immersion in the online would be quite stressful for your target audience. Therefore, companies should take into account the information field of their consumers. Although social media used to be reserved for communicating with friends, now it has become a platform where businesses, different individuals could share different ideas. This became very clear during the pandemic, when many organizations began to switch to their profiles 
en masse, or began to create them, on various social networks and on various sites. Prolonged restrictions on population mobility and consumer caution could lead to another decline in consumption. Increasing the number of Internet users and reducing the cost of attracting customers in the digital environment put businesses in need of transforming marketing strategies into online promotion, in which the main focus should be on the user. The current crisis allows scarce niche companies to gain instant benefits. However, in a long-term strategy, such an approach threatens to acquire a negative reputation. Therefore, in a longterm strategy, those who use the time of self-isolation to establish contact with users, care about the social responsibility of business, develop social commerce - would be able to increase their competitiveness at times, creating a loyal customer base. In addition, it is important to remember that the competition in the online space is not with ordinary opponents on the subject, but with innovative public companies. The main format of content consumption online is a news feed, so the quality of the company's presence in the consumer information field is of great importance. In the digital environment, companies should invest in an online presence. But one presence is not enough: you need to make it effective. Therefore, it is necessary to invest in online reputation, ie likes, online reviews, reposts - the so-called thought marketing. Companies should also innovate in the ways they communicate with their customers and develop new sales channels (Table 2).

\section{Table 2. Innovations in online communication with the customers according to research their} behavior

\begin{tabular}{l}
\hline Method of communication: \\
\hline 1. Communication via messengers (Telegram / Viber / WhatsApp) \\
2. Development of delivery (bonuses, discounts, free delivery) \\
3. Development of online sales (online store, bonuses for online shopping) \\
4. Online communication \\
5. Telephone consultations, remote consultation, online consultation \\
6. Increasing advertising (SMS, radio, TV, Tik-Tok, personal site) \\
7. Video support, video sales, video presentations \\
Sources: developed by the authors.
\end{tabular}

In addition, firms should facilitate the possibility of feedback from their customers, including negative ones. The advantage would be that they would be able to learn about possible problems, correct them and make a better personal image. This decision would not only block the negative discussion of the company with relatives, but also increase the attitude of customers to the company. By receiving feedback, companies would be able to quickly implement various interesting proposals, gaining a number of benefits. In times of crisis, it is better not just to talk to customers, but also to demonstrate change, because it would help to establish openness and gain trust among consumers. And again, these would mean that you have to spend for these processes.

Conclusions. Before COVID-19 the development of marketing has reached a certain maturity when every self-respecting business began to use marketing tools, and universities and other educational institutions are seriously engaged in training personnel for a prestigious and promising profession. Thus, the role of marketing in the crisis becomes fundamental. And only with the help of marketing, it is possible to optimize production, occupy the opened niches, and, importantly, attract large investments.

Consumer tastes are highly individualized. And digital environment could use it via marketing instruments. Of course, it should be used in tourism marketing. And this must be taken into account in marketing strategies all over the world and Azerbaijan. The winner is the business that not only gives the opportunity to choose for customers but also offers something unique taking into account their behavior. And this is the main task of digital marketing today. The COVID-19 pandemic has become a global challenge that has changed and continues to change consumer behavior around the world. Most 
consumers have switched to an online environment. Demand for some goods has decreased, while for others, on the contrary, it has increased. For many businesses that are ready to offer their products and services online, there are many opportunities. But entrepreneurs at this time need to be very careful, because the priority changes every day.

Author Contributions: conceptualization, F. R., A. R. and M. M.; methodology, F. R., A. R. and M. M.; software, M. M. and A. R.; validation, F. R. and M. M.; formal analysis, A. R.; investigation, A. R.; resources, F. R.; data curation, F. R, M. M. and A. R.; writing-original draft preparation, M .M. and A. R.; writing-review and editing, F.R. and M. M.; visualization, A. R.; supervision, F. R. and M. M.; project administration, F. R.

Funding: This research received no external funding.

\section{References} [Link]

Armano, D. (2020). COVID-19 will be remembered as the «Great Accelerator» of digital transformation. Forbes. Retrieved from

Bai, Y., Yao, L., Wei, T., Tian, F., Jin, D. Y., Chen, L., \& Wang, M. (2020). Presumed Asymptomatic Carrier Transmission of COVID-19. JAMA-Journal of the American Medical Association, 323(14). [Google Scholar] [CrossRef]

Bilan, Y., Chudy-Laskowska, K., Szczygieł, E., \& Piecuch, T. (2021). People's Behavior, in the Context of Living Standards Changes and Sustainable Development, Exemplified by the Carpathian Euroregion. Acta Polytechnica Hungarica, 18(2). [Google Scholar] [CrossRef]

Biswal, B., Ashish, D., Guo, j., Bui, J., \& Lau, S. (2020). Going digital: insights to optimise online insurance in Asia. Swiss Re Institute. Retrieved from [Link]

Carnevale, J. B., \& Hatak, I. (2020). Employee adjustment and well-being in the era of COVID-19: Implications for human resource management. Journal of Business Research, 116, 183-187. [Google Scholar] [CrossRef]

Chen, Z. L., Zhang, Q., Lu, Y., Guo, Z. M., Zhang, X., Zhang, W. J., ... \& Lu, J. H. (2020). Distribution of the COVID-19 epidemic and correlation with population emigration from Wuhan, China. Chinese Medical Journal, 133(9). [Google Scholar] [CrossRef]

Donthu, N., \& Gustafsson, A. (2020). Effects of COVID-19 on business and research. Journal of business research, 117, 284. [Google Scholar] [CrossRef]

Dutta, P., Dutta, U., Hasan, S., Sarkar, S., \& Sana, T. (2020). Educate, Empower And Protect People Through Timely Authentic Information: Explore How Bangladeshi Newspapers Response To COVID-19 Pandemic. SocioEconomic Challenges, 4(3), 94-104 [Google Scholar] [CrossRef]

Farseev, A., Chu-Farseeva, Y. Y., Qi, Y., \& Loo, D. B. (2020). Understanding economic and health factors impacting the spread of COVID-19 disease. medRxiv. [Google Scholar] [CrossRef]

Gritsayenko, I. (2020). How the COVID-19 epidemic affected the behavior of the Internet audience. European Business Association. SODA Creative \& Digital. Retrieved from [Link]

Heubl, B. (2020).Covid-19 cycling infrastructure building spree overlooks safety needs. E\&T. Retrieved from [Link]

Ji, Y., Ma, Z., Peppelenbosch, M. P., \& Pan, Q. (2020). Potential association between COVID-19 mortality and health-care resource availability. The Lancet Global Health, 8(4), e480. [Google Scholar] [CrossRef]

Kemp, S. (2021). DigitaL 2021: global overview report. Retrieved from [Link]

Kuzmenko, O., Vasylieva, T., Vojtovič, S., Chygryn, O., \& Snieška, V. (2020). Why do regions differ in vulnerability to covid-19? Spatial nonlinear modeling of social and economic patterns. Economics \& Sociology, 13(4), 318-340. [Google Scholar] [CrossRef] Kwilinski, A., Vyshnevskyi, O., \& Dzwigol, H. (2020). Digitalization of the EU Economies and People at Risk of Poverty or Social Exclusion. Journal of Risk and Financial Management, 1377), 142. [Google Scholar] [CrossRef]

Perez, S. (2020). Grocery delivery apps see record downloads amid coronavirus outbreak, TechCrunch. Retrieved from [Link] Rahmanov, F., Aliyeva, R., Rosokhata, A. S., \& Letunovska, N. Y. (2020). Tourism management in Azerbaijan under sustainable development: impact of COVID-19. Marketing and Management of Innovations, 3, 195-207. [Google Scholar] [CrossRef]

Rosokhata, A. S., Rybina, O. I., Derykolenko, A. O., \& Makerska, V. (2020). Improving the Classification of Digital Marketing Tools for the Industrial Goods Promotion in the Globalization Context. Research in World Economy, 11 (4), 42-52. [Google Scholar]

Rosokhata, A., \& Sager, L. (2020). Individual issues of economic security: the study of the impact of changes in migration processes on countries economic and innovative development. Visnyk of Sumy State University. Economics series, 1, 62-74. Retrieved from [Link]

Rudenko, L. A., Smiianov, V. A., \& Smiianova, O. I. (2020). Basic principles of behavioral economics and prospects for their application in the public health system. Wiadomosci Lekarskie, 73(9), 2026-2030. [Google Scholar] [CrossRef]

Saher, L., Stoyanets, N., \& Butrym, O. (2020, April). Impact Of Highly Qualified Personnels Migration On Economic And Innovative Development. In 35th IBIMA Conference (pp. 1-2). Retrieved from [Link] 
Sheth, J. (2020). Impact of Covid-19 on consumer behavior: Will the old habits return or die?. Journal of Business Research, 117, 280-283. [Google Scholar] [CrossRef]

Theodoridis, P. K., \& Kavoura, A. (2021, March). The Impact of COVID-19 on Consumer Behaviour: The Case of Greece. In Strategic Innovative Marketing and Tourism in the COVID-19 Era: 9th ICSIMAT Conference 2020(pp. 11-18). Springer International Publishing. [Google Scholar] [CrossRef]

Us, Y. O., Pimonenko, T. V., Tambovceva, T., \& Segers, J. P. (2020). Green transformations in the healthcare system: the covid-19 impact. Health Economics and Management Review, 1, 48-59. [Google Scholar] [CrossRef]

Vasilyeva, T., Kuzmenko, O., Bozhenko, V., \& Kolotilina, O. (2019). Assessing the dynamics of bifurcation transformations in the economy. In SHS Web of Conferences (Vol. 65, p. 04006). EDP Sciences. [Google Scholar] [CrossRef]

Vasylieva, T., Lyulyov, O., Pimonenko, T., Vojtovič, S., \& Bilan, Y. (2020). Financial, socio-economic, environmental and public health patterns of creating regional roadmaps to prevent the spread of the covid-19 epidemic. Financial and credit activity: problems of theory and practice, 4(35), 295-310.

Yelnikova, Y. V., \& Kwilinski, A. (2020). Impact-Investing in The Healthcare in Terms of the New Socially Responsible State Investment Policy. Business Ethics and Leadership, 4(3), 57-64. [Google Scholar] [CrossRef]

Рахманов Фархад Панах оглі, Dr.Sc., Азербайджанський державний економічний університет, Азербайджанська Республіка

Мурсалов Муслім Мурсал оглі, Ph.D., Азербайджанський державний економічний університет, Азербайджанська Республіка

Анна Росохата, к.е.н., Сумський державний університет, Україна

Поведінка споживачів у цифрову еру: вплив COVID-19

Метою статті є дослідження впливу цифровізації, прискореною пандемією COVID-19, на зміну поведінки споживачів. Головними методами боротьби з пандемією стали збільшення соціальної дистанції та низка карантинних заходів, які значно вплинули не лише на економіку країн, а й поведінку кожного окремого індивіда. Так, споживачі задовольняють свої потреби за допомогою цифррових інструментів та можливостей. У статті проаналізовано зміну поведінки споживачів в цифровому просторі після настання пандемії. Методологічною основою дослідження є методи аналітичного та порівняльного аналізу. У роботі проаналізовано тенденції у зміні споживчого попиту та уподобань на туристичні та рекреаційні послуги за допомогою інструментарію Google Trends. Емпіричний аналіз базується на даних соціологічного опитування громадян Азербайджану проведеного з 13 по 21 квітня 2020 колективом дослідників з Університету Нортгемптона (Великобританія), Національного інституту геофізики, геодезії та географії - Болгарської академії наук, Університету національної та світової економіки (Болгарія). За результатами проведеного дослідження визначено основні виклики цифровізації в маркетингу, а саме: стрімке зростання популярності цифррових інструментів з моменту настання пандемії COVID-19 та збереження максимально високих позицій після послаблення обмежувальних заходів, де підприємницький сектор продемонстрував свою неготовність до цифрової трансформації; перша взаємодія споживача в цифровому середовищі формує стале уявлення, очікування та досвід взаємодії з конкретними брендами. За результатами дослідження авторами изапропоновано рекомендації щодо побудови взаємовідносин зі споживачами, маракетингові інтсрументи підвищення рівня їх лояльності в цифровому середовищі. Результати даного дослідження можуть бути корисними представникам підприємницьких структур та органів самоврядування різних рівнів.

Ключові слова: поведінка споживачів, вплив COVID-19, цифррове середовище, туризм в Азербайджані, індивідуальні зміни споживачів. 